\title{
Diante da Dor de Frida: Reflexões Sobre a Relação Médico- Paciente e a Humanização da Medicina
}

\author{
Duarte, Josiane Aparecida; Oliveira, Bruna Miclos de; Vianna, Lucy Gomes; Bezerra, \\ Armando José China \\ Universidade Católica de Brasília — josianeduartemed@gmail.com
}

Introdução:Já dizia William Osler: "Os estudos humanísticos são os hormônios que catalisam o pensamento e humanizam a prática médica."Novas demandas sociais têm chegado aos consultórios médicos (violência, alcoolismo, depressão, etc.) e exigem dos profissionais habilidades que vão além dos conhecimentos técnico-científicos. Dessa forma, a formação do médico exige atributos que ampliem sua atuação de modo a capacitá-lo a uma compreensão mais ampla do paciente e de suas demandas, o que vai se expressar nas atitudes, posturas e condutas adotadas nessa relação. Nessa perspectiva, moldar-se-á uma profunda dimensão de solidariedade que possibilite entender o paciente como um sujeito que sofre e precisa ser acolhido. a aquisição de habilidades biomédicas deve, pois, ser equivalente à formação humanitária e ética do profissional que terá, como missão, cuidar do sofrimento humano.Objetivo: Tendo como referência o atual panorama de humanização da saúde, propõese aqui pensar, por meio de algumas obras marcantes da biografia de Frida Kahlo, o sofrimento e o papel do médico na história de vida dos seus pacientes.Metodologia:o presente trabalho foi construído a partir de uma análise relacionando o estudo de revisão bibliográfica feito da vida e obra de Frida Kahlo e da relação médico paciente. Resultados:Frida Kahlo nasceu em 1907 na cidade de Coyoacán, México. a dor, o sofrimento e, principalmente, o inconformismo nunca estiveram tão presentes quanto na história de Frida, que se tornou um grande exemplo de superação. Kahlo lutara pela vida, que, para ela, era mais importante do que qualquer dor e sofrer.Sendo protagonista de uma série de enfermidades, acidentes, lesões e operações, o que protegia Frida eram o amor e a arte. Dr. Farill também foi uma personalidade que teve importante participação no processo de recuperação de Frida. Ele é exemplo de uma relação médicopaciente que ilustra e incorpora todas as premissas da humanização. Trata-se de um cuidado baseado na confiança e no respeito, condição fundamental ao sucesso da atenção médica dada àquele ser fragilizado e carente. Além disso, é possível enxergar nessa relação mútua admiração, o que a torna mais afetiva e acolhedora. por ser a medicina ciência e arte, a sensibilidade de quem a pratica é indispensável à relação terapêutica.Dessa forma, a formação do médico exige atributos que ampliem sua atuação de modo a capacitá-lo a uma compreensão mais ampla do paciente e de suas demandas, o que vai se expressar nas atitudes, posturas e condutas adotadas nessa relação. Conclusão: Nem mesmo os grandes deuses da mitologia estavam livres da dor. a história de Frida é marcada por dificuldades, erros e incoerências, mas também por força, coragem determinação e amor à sua arte. Conhecê-la contribui significativamente no processo de humanização e sensibilização do profissional de saúde, visto que o desafio deste é conviver diariamente com o sofrimento e com a dor.

Duarte, Josiane Aparecida; Oliveira, Bruna Miclos de; Vianna, Lucy Gomes; Bezerra, Armando José China. Diante da Dor de Frida: Reflexões Sobre a Relação Médico-Paciente e a Humanização da Medicina. In: Anais do Congresso Internacional de Humanidades \& Humanização em Saúde [= Blucher Medical Proceedings, num.2, vol.1]. São Paulo: Editora Blucher, 2014. ISSN 2357-7282

DOI 10.5151/medpro-cihhs-10774 